\title{
Adaptasi dan Pengujian Alat Ukur Team Trust Milik Costa dan Anderson (2011) di Indonesia
}

\author{
Salma Al Zahra, Medianta Tarigan, Diah Zaleha Wyandini \\ Universitas Pendidikan Indonesia, Indonesia \\ salmalzahra@student.upi.edu
}

\begin{abstract}
The aim of this study was to examine the validity and reliability of Team Trust Scale which is adapted from Costa and Anderson (20II) in Indonesia. Team Trust Scale consist of 21 items with 4 dimensions is propensity to trust, perceived trustworthiness, cooperative behaviors and monitoring. The subject of this study is 572 workers that works within team in Indonesia. The result of confirmatory factor analysis show this scale's model is good fit with fit indexes 0,07 (RMSEA), 0,04 (SRMR), 0,93 (CFI) dan 0,92 (TLI). Also for the result of convergent and discriminant validity show team trust scale that adapted to Indonesia is valid. For the reliability with coefficient Alpha Cronbach method is 0,930 and it show this scale is reliable. Moreover, this study using comparative test for characteristic of participants such work field, work period, position, amount personnel in unit and division/department.
\end{abstract}

Keywords: Reliability; validity; team trust

\section{Abstrak}

Tujuan dari penelitian ini adalah untuk menguji validitas dan reliabilitas alat ukur Team Trust yang diadaptasi dari Costa dan Anderson (20II) di Indonesia. Skala Team Trust terdiri 2I item dengan 4 dimensi yaitu propensity to trust, perceived trustworthiness, cooperative behaviors and monitoring behaviors. Subjek dari penelitian ini adalah 572 karyawan yang bekerja dalam tim di Indonesia. Hasil uji confirmatory factor analysis menunjukkan bahwa model fit dengan nilai indeks kecocokan sebesar 0,07 (RMSEA), 0,04 (SRMR), 0,93 (CFI) dan 0,92 (TLI). Selain itu, uji validitas konvergen dan diskriminan menunjukkan bahwa alat ukur team trust yang diadaptasi ke Indonesia valid. Sementara itu, reliabilitas dengan koefisien Alpha Cronbach sebesar 0,930 dan menunjukkan bahwa alat ukur ini reliabel. Selain itu penelitian ini menggunakan uji beda pada karakteristik partisipan berupa bidang pekerjaan, lama kerja, jabatan, jumlah anggota dalam unit dan jumlah anggota dalam divisi/departemen.

Kata kunci: Reliabilitas; validitas; kepercayaan tim 


\section{Pendahuluan}

Organisasi yang terdiri dari beberapa individu akan dihadapkan dengan perbedaan kebutuhan namun tetap memiliki tujuan yang sama yaitu mencapai keberhasilan organisasi tersebut (Bakti, 2013; Pramudyo, 2013; Susiawan dan Muhid, 2015). Untuk mencapai tujuan organisasi, tidak hanya dipengaruhi oleh kualitas sumber daya manusia yang terdapat di organisasi tersebut. Menurut Costa dan Anderson (20II), keberhasilan suatu organisasi juga dipengaruhi oleh kerjasama yang dibangun oleh setiap individu dalam organisasi tersebut sebagai tim. Namun tidak semua tim dalam suatu organisasi mampu bekerjasama secara efektif dan efisien. Membangun kerjasama dalam tim yang efektif dan efisien, membutuhkan kepercayaan pada setiap anggota dalam tim tersebut (Spector dan Jones, 2004). Sehingga, kepercayaan dalam tim menjadi elemen yang mampu menunjang keberhasilan organisasi untuk mencapai tujuannya.

Kepercayaan merupakan salah satu elemen penting dalam suatu organisasi baik pada karyawan secara individual, tim dan organisasi itu sendiri (Kramer, 1999; Puusa dan Tolvanen, 2006; Norman, Avolio dan Luthans, 2010; Raharso, 20II; Costa dan Anderson, 20II; Owonikoko, 2016). Kepercayaan dalam tim merupakan elemen dasar yang memengaruhi kecenderungan individu untuk memberikan kepercayaan kepada rekan kerjanya serta mempersepsikan bahwa rekan kerjanya juga memberikan kepercayaan terhadap dirinya (Costa dan Anderson, 201 I; Reina, Reina dan Hudnut, 2017). Kemudian, kepercayaan dalam juga membantu organisasi dalam mencapai kesuksesan baik secara kualitas maupun finansial, kinerja, efektivitas dan efisiensi organisasi (Dirks dan Ferrin, 2002; Kramer dan Tyler, I996; Lewickit dkk, I998; Mayer dan Davis, I999; Kerfoot dalam Utamaningsih, 2009; Yozgat dan Mesekiran, 2016).

Namun, untuk melihat kepercayaan dalam tim tidak dapat hanya melalui observasi atau penilaian secara umum. Untuk melihat kepercayaan dalam tim dibutuhkan alat ukur guna menunjukkan hasil pengukuran yang tepat (Azwar, 2015). Penggunaan alat ukur ini guna menunjukkan hasil pengukuran yang valid dan relaibel. Guna mendapatkan hasil tersebut dibutuhkan alat ukur yang memiliki reliabilitas dan validitas yang baik (Mantondang, 2009). Sehingga dibutuhkan alat ukur yang sudah teruji reliabilitas dan validitasnya untuk digunakan pada penelitian-penelitian di Indonesia. Penelitian mengenai alat ukur team trust belum banyak dilakukan dan khususnya di Indonesia belum pernah dilakukan.

Pada tahun 20II, Costa dan Anderson mengembangkan skala trust in teams yang diuji dengan dua setting pekerjaan yang berbeda yaitu di rumah sakit dan pekerja sosial. Hasilnya menunjukkan terdapat 2I item dengan 4 dimensi yaitu propensity to trust, perceived trustworthiness, cooperative behaviors dan monitoring behaviors. Skala trust in teams yang dikembangkan oleh Costa dan Anderson (20II) ini mampu digunakan pada berbagai setting pekerjaan khususnya yang menerapkan kerjasama dalam suatu tim.

Namun, Costa dan Anderson (20II) menyarankan untuk melakukan penelitian terkait skala ini dengan setting pekerjaan yang lebih bervariasi. Selain variasi jenis pekerjaan, bahasa yang digunakan dalam alat ukur juga perlu disesuaikan dengan lokasi penggunaan alat ukur tersebut. Menurut Kim dan Berry (I993), Kim (2000) dan Bakti (2013), tidak semua alat ukur yang dari barat mampu cocok dengan negara lainnya khususnya Indonesia. Selain itu, alat ukur barat yang menggunakan bahasa inggris, tidak mampu digunakan secara general bagi orang Indonesia yang menggunakan bahasa utama yaitu bahasa Indonesia. Bahasa dalam suatu alat ukur menjadi salah satu aspek yang penting karena memengaruhi uji keterbacaan alat ukur tersebut (Azwar, 2015). Sehingga dibutuhkan alat ukur berbahasa Indonesia yang memiliki reliabilitas dan validitas yang baik untuk digunakan pada penelitian yang mengambil partisipan orang Indonesia.

Alat ukur berbahasa Indonesia dapat dihasilkan dengan mengadaptasi alat ukur dari negara lain yang kemudian akan dilakukan pengujian validitas dan reliabilitasnya. Proses pengadaptasian alat ukur ini berupa mengalihbahasakan setiap item yang terdapat dalam alat ukur, pengujian terhadap sampel dan analisis data yang berupa pengujian validitas serta reliabilitasnya (Widodo, 2006; Wicaksana dkk, 20I2; Grasiaswaty, Juwita dan Setyasih, 20I4; Rachmayani dan Ramdhani, 20I4; Riva, Gorini, Cutica, Mazzocco dan Pravettoni, 
2015; Kirikkanat dan Soyer, 2016; Soler dkk, 2016; Bakioglu dan Turkum, 20I7; Toprak dan Karakus, 2018).

Pengujian validitas alat ukur dapat dilakukan dengan membandingkan alat ukur tersebut dengan alat ukur yang memiliki fungsi pengukuran yang sama dan berbeda (Cohen dan Swerdlik, 2009; Schafer, Wang dan Wang, 2009; Cozby dan Bates, 2015; Magnusson dalam Azwar, 2015). Salah satu alat ukur yang memiliki fungsi pengukuran aspek yang sama dengan team trust adalah skala komitmen organisasi yang diadaptasi ke Indonesia oleh Ingarianti (2015) dan skala Employee Engagement yang dikembangkan oleh Titien (2016). Sementara itu, alat ukur yang memiliki fungsi pengukuran yang berbeda adalah alat ukur rasa syukur yang di adaptasi ke Indonesia oleh Listiandini (2015) yang belum pernah dilakukan penelitian terkait korelasi antara team trust dengan rasa syukur. Sehingga peneliti mengasumsikan bahwa kedua alat ukur tersebut mengukur konstruk yang berbeda.

\section{Team Trust}

Kepercayaan dalam tim merupakan elemen dasar yang memengaruhi kecenderungan individu untuk memberikan kepercayaan kepada rekan kerjanya serta mempersepsikan bahwa rekan kerjanya juga memberikan kepercayaan terhadap dirinya (Costa dan Anderson, 20II). Kepercayaan dalam tim ini menunjang kerjasama dalam suatu tim yang kemudian akan mengarahkan pada keberhasilan tim tersebut dalam mencapai tujuannya (Tyler, 2003; Spector dan jones, 2004; Costa dan Anderson, 201 I).

Berdasarkan penelitian yang dilakukan oleh Costa dan Anderson (20II), terdapat empat dimensi yang terdapat dalam kepercayaan dalam tim yaitu propensity to trust, perceived trustworthiness, cooperative behavior dan monitoring behaviors. Dimensi-dimensi tersebut akan menunjukkan sejauh mana seorang karyawan percaya terhadap timnya dan mempersepsikan bahwa timnya juga memberikan kepercayaan terhadap dirinya.

\section{Penelitian Alat Ukur Team Trust}

Alat ukur utama yang digunakan dalam penelitian ini merupakan alat ukur team trust yang dikembangkan oleh Costa dan Anderson (20I I). Team Trust Scale (Costa dan Anderson, 20I I) terdiri dari empat dimensi yaitu propensity to trust, perceived trustworthiness, cooperative behaviors dan monitoring behaviors. Total item yang terdapat dalam Team Trust Scale adalah 2I item. Alat ukur ini diuji kepada karyawan yang bekerja di rumah sakit dan organisasi sosial yang berada di bawah naungan pemerintahan Negara Belanda. Hasil analisis Exploratory Factor Analysis (EFA) menunjukkan nilai The Kaiser-Mayer-Olkin (KMO) sebesar 0,83 dan total varians sebesar $55,1 \%$.

Kemudian, hasil analisis Confirmatory Factor Analysis (CFA) menunjukkan kecocokan dengan teori yang menunjukkan nilai indeks kecocokan CFI 0.94, GFI 0.83, RMSEA 0.05 dan SRMR 0.07 dimana masuk dalam kategori good fit. Sementara itu, pengujian reliabilitas menunjukkan reliabilitas Alpha Cronbach dimensi propensity to trust sebesar 0.78 , dimensi perceived trustworthiness sebesar 0.88 , dimensi cooperative behaviors sebesar 0.87 dan dimensi monitoring behaviors sebesar 0.70 yang menunjukkan bahwa alat ukur ini reliabel.

\section{Metode}

Penelitian ini dilakukan guna mengadaptasi dan menguji skala team trust yang sebelumnya disusun oleh Costa dan Anderson (20II). Pendekatan yang digunakan dalam penelitian ini adalah metode kuantitatif. Populasi dalam penelitian ini adalah karyawan di Indonesia yang memiliki tim dalam melakukan pekerjaannya. Teknik sampling yang digunakan dalam penelitian ini adalah non-probability sampling yaitu dengan quota 
sampling dimana partisipan diambil sesuai dengan jumlah yang dibutuhkan oleh peneliti hingga dapat mewakili populasi dari penelitian (Kothari, 2004; Taherdoost, 2016). Jumlah partisipan dalam penelitian ini sebanyak 572 karyawan yang bekerja dalam tim di Indonesia. Proses pengambilan data dilakukan secara offline dan online.

Pengujian yang dilakukan berupa validitas konstruk yaitu Confirmatory Factor Analysis yang menggunakan perangkat lunak JASP sementara validitas konvergen dan diskriminan, estimasi koefisien Alpha Cronbach dan uji beda menggunakan perangkat lunak SPSS.

\section{Hasil dan Pembahasan}

Untuk melihat apakah suatu alat ukur memiliki kualitas yang baik, dapat menggunakan pengujian validitas. Validitas menunjukkan ketepatan suatu alat ukur dalam mengukur atribut psikologi yang diukurnya (Kimberlin dan Winterstein, 2008; Hair, Black, Babin dan Anderson, 20I0; Shaughnessy dkk, 20I2). Jenis validitas yang digunakan dalam penelitian ini adalah validitas konstruk yang menggunakan pendekatan factor analysis yaitu confirmatory factor analysis. Pendekatan ini berfungsi untuk menguji hipotesis atau untuk mengkonfirmasi teori mengenai suatu faktor yang diasumsikan (Anastasia dan Urbina, I997).

Pengujian confirmatory factor analysis ini dilakukan dengan menggunakan bantuan perangkat lunak JASP. Analisis Confirmatory Factor Analysis (CFA) ini menggunakan data sebanyak 572 pada alat ukur team trust yang memiliki 4 dimensi. Dimensi-dimensi tersebut terdiri dari variabel-variabel yang dapat diobservasi berupa 2I item dimana dimensi propensity to trust, perceived trustworthiness dan cooperative behaviors terdiri dari 6 item, sementara dimensi monitoring behaviors terdiri dari 3 item.

Indeks kecocokan yang digunakan untuk menguji model fit dalam penelitian ini diantaranya adalah Goodness of Fit Index (GFI), Root Mean Square Error of Approximation (RMSEA), Standardized Root Mean Residual (SRMR), Comparative Fit Index (CFI), dan Tucker Lewis Index (TLI). Hasil analisis menunjukkan bahwa alat ukur Team Trust yang terdiri dari 4 dimensi dan 2I item tidak fit. Nilai indeks fit atau kecocokan model dari alat ukur Team Trust $(\mathrm{N}=572)$ setelah dilakukan analisis confirmatory factor analysis (CFA) pada model 4 faktor yaitu nilai indeks kecocokan absolut Root Means Square Error of Approximation (RMSEA) sebesar 0,I I dan Standardized Root Mean Square (SRMR) sebesar 0,09.

Sementara berdasarkan nilai indeks kecocokan inkremental menunjukkan hasil Comparative Fit Indeks (CFI) sebesar 0,80 dan Tucker Lewis Indeks (TLI) sebesar 0,77. Berdasarkan hasil CFA tersebut, nilai indeks nilai Root Means Square Error of Approximation (RMSEA) sebesar O,I I menunjukkan bahwa model kurang fit karena nilanya $>0,08$ dan nilai Standardized Root Mean Square (SRMR) sebesar 0,09 menunjukkan model kurang fit karena nilainya >0,05 (Byrne, 1998; Hair, Black, Babin dan Anderson, 2010; Cangur \& Ercan, 2015). Menurut MacCallum, Browne dan Sugawara (1996) nilai RMSEA menunjukkan suatu alat ukur fit dengan rentang $0.05 \leq \mathrm{x} \leq 0.08$ sementara nilai SRMR di bawah 0,05. Kemudian berdasarkan nilai indeks kecocokan inkremental menunjukkan hasil Comparative Fit Indeks (CFI) sebesar 0,80 dan nilai Tucker Lewis Indeks (TLI) sebesar 0,77 yang menunjukkan bahwa model tersebut kurang fit karena kedua nilainya $<$ 0,90 (Ghozali dan Fuad, 2008).

Setelah melakukan pengujian confirmatory factor analysis, peneliti melakukan modification indices guna memperoleh kecocokan pada alat ukur yang telah diadaptasi dengan data yang didapatkan. Menurut Furr dan Bacharach (20I4), modification indices merupakan salah satu metode dalam Confirmatory Factor Analysis (CFA) yang menunjukkan beberapa jalur untuk meningkatkan indeks fit suatu model. Langkah-langkah yang dilakukan peneliti dalam melakukan modification indices berupa mengkorelasikan item-item yang terdapat dalam alat ukur team trust dan mengeliminasi beberapa item dengan melihat nilai standardized residual covariances. Proses ini juga dilakukan dengan bantuan perangkat lunak JASP. 
Tabel I. Indeks Ukuran Kecocokan Setelah dan Sebelum Dilakukan Modification Indices dan Eliminasi Item

\begin{tabular}{llcc}
\hline Jenis Indeks & Indeks Kecocokan Model & Sebelum & Sesudah \\
\cline { 2 - 3 } Indeks Kecocokan Absolut & Root Means Square Error of Approximation & Nilai Indeks & \\
& (RMSEA) & & 0,07 \\
& Standardized Root Mean Square (SRMR) & 0,09 & 0,04 \\
Indeks Kecocokan Inkremental & 0,80 & 0,93 \\
& Comparative Fit Indeks (CFI) & 0,77 & 0,92 \\
\hline
\end{tabular}

Hasil dari metode tersebut tersebut membuat 3 item harus dibuang yaitu item 6 dari dimensi propensity to trust, item I0 dari dimensi perceived trustworthiness dan item I 6 dari dimensi cooperative behaviors. Tabel I menunjukkan hasil indeks kecocokan sebelum dan sesudah dilakukan modification indices. Hasil perhitungan statistik analisis CFA ( $=572)$ setelah dilakukan modification indices dan eliminasi item menunjukkan nilai indeks kecocokan absolut good fit atau kecocokan model yang baik dengan data yang diperoleh. Hasilnya menunjukkan nilai indeks kecocokan pada model 4 faktor skala team trust setelah dilakukan modification indices dengan nilai Root Means Square Error of Approximation (RMSEA) sebesar 0,07 dan Standardized Root Mean Square (SRMR) sebesar 0,04.

Sementara berdasarkan nilai indeks kecocokan inkremental menunjukkan hasil Comparative Fit Indeks (CFI) sebesar 0,93 dan Tucker Lewis Indeks (TLI) sebesar 0,92. Gambar I menunjukkan model skala team trust setelah dilakukan modification indices.

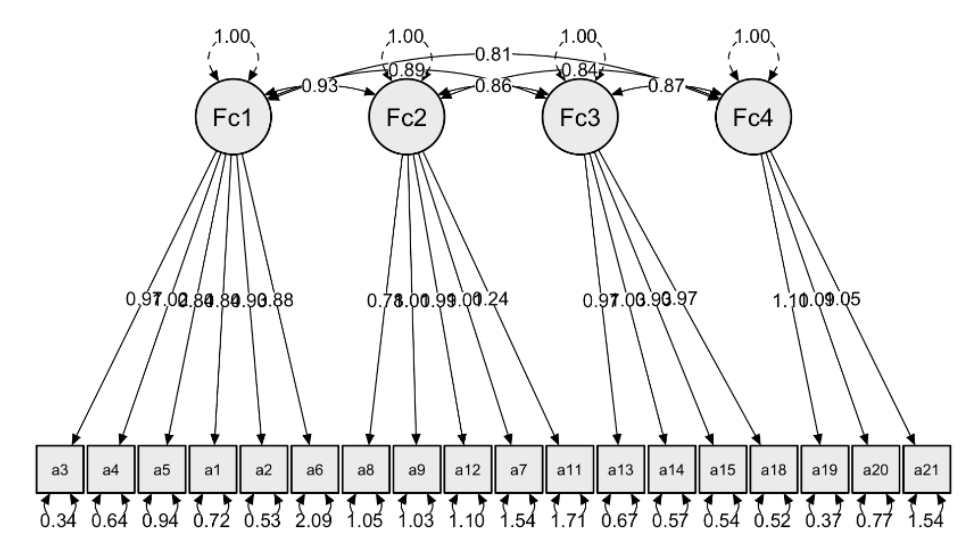

Gambar I. Model 4 Faktor Alat Ukur Team Trust sesudah dilakukan Modification Indices

Selain menguji validitas dengan menggunakan pendekatan validitas faktorial, peneliti juga menggunakan pendekatan validitas lainnya yaitu validitas konvergen dan diksriminan. Validitas konvergen menunjukkan suatu alat ukur valid ketika hasil korelasi skor antar alat ukur yang mengukur konstruk yang sama menunjukkan hasil yang sesuai atau berkorelasi tinggi (Cohen dan Swerdlik, 2009; Schafer, Wang dan Wang, 2009; Cozby dan Bates, 2015). Dalam penelitian ini, peneliti menggunakan alat ukur employee engagement (Titien, 20I6) dan komitmen organisasi (Ingarianti, 20I5) dimana kedua alat ukur tersebut sudah diadaptasi ke Indonesia.

Hasil pengujian validitas konvergen menunjukkan adanya hubungan yang moderat antara alat ukur team trust dengan alat ukur employee engagement nilai pearson correlation sebesar 0,53. Kemudian validitas konvergen pada alat ukur team trust dengan komitmen organisasi menunjukkan adanya hubungan yang moderat dengan nilai pearson correlation sebesar 0,61. Menurut Guilford (1956), nilai korelasi tersebut yang 
cukup yakni sebesar 0,53 dan 0,6I yang menunjukkan adanya kesesuaian yang moderat antara alat ukur tersebut ( $=572)$. Tabel 2 menunjukkan hasil validitas konvergen alat ukur team trust dengan employee engagement sementara tabel 3 menunjukkan hasil validitas konvergen alat ukur team trust dengan komitmen organisasi.

Tabel 2. Korelasi Alat Ukur Team Trust dengan Alat Ukur Employee Engagement

\begin{tabular}{llcc}
\hline & & TEAM & EMPLOYEE \\
TEAM & Pearson Correlation & TRUST & ENGAGEMENT \\
TRUST & Sig. (2-tailed) & &, $535^{\circ \circ}$ \\
& $N$ & 572 &, 000 \\
EMPLOYEE & Pearson Correlation &, $535^{5 \circ}$ & 572 \\
ENGAGEMENT & Sig. (2-tailed) &, 000 & $\mathrm{I}$ \\
& $\mathrm{N}$ & 572 & 572 \\
& & \\
\hline
\end{tabular}

Tabel 3. Korelasi Alat Ukur Team Trust dengan Alat Ukur Komitmen Organisasi

\begin{tabular}{|c|c|c|c|}
\hline & & TEAM & KOMITMEN \\
\hline & & TRUST & ORGANISASI \\
\hline TEAM & Pearson Correlation & I &, $610^{+\infty}$ \\
\hline KOMITMEN & Pearson Correlation & $610^{+\infty}$ & I \\
\hline \multirow[t]{2}{*}{ ORGANISASI } & Sig. (2-tailed) & , 000 & \\
\hline & $\mathrm{N}$ & 572 & 572 \\
\hline
\end{tabular}

Perhitungan berikutnya adalah validitas diskriminan yang menunjukkan valid atau tidaknya suatu alat ukur dengan mengkorelasikan skor alat ukur yang diasumsikan mengukur konstruk yang berbeda (Kazdin, I995; Cohen dan Swerdlik, 2009; Schafer, Wang dan Wang, 2009; Cozby dan Bates, 20I5; Santoso, 2017). Alat ukur yang digunakan sebagai pembanding diskriminan adalah alat ukur rasa syukur (Listiandini, 20I5) yang belum pernah dilakukan penelitian terkait korelasi antara team trust dengan rasa syukur. Sehingga peneliti mengasumsikan bahwa kedua alat ukur tersebut mengukur konstruk yang berbeda.

Tabel 4. Korelasi Alat Ukur Team Trust dengan Alat Ukur Rasa Syukur

\begin{tabular}{llll}
\hline & & TEAM TRUST & RASA SYUKUR \\
TEAM & Pearson Correlation & I &, 069 \\
TRUST & Sig. (2-tailed) & & ,II8 \\
& N & 572 & 517 \\
RASA & Pearson Correlation &, 069 & I \\
SYUKUR & Sig. (2-tailed) & ,118 & \\
& $\mathrm{N}$ & 517 & 517 \\
\hline
\end{tabular}

Tabel 4 menunjukkan hasil validitas diskriminan alat ukur team trust dengan rasa syukur. Hasil pengujian validitas diskriminan menunjukkan bahwa terdapat hubungan sangat rendah antara alat ukur team trust dengan alat ukur rasa syukur dengan nilai pearson correlation sebesar 0,06 $(\mathrm{N}=5 \mathrm{I7})$. Dari definisi terkait validitas diskriminan tersebut menunjukkan bahwa alat ukur team trust yang diadaptasi ke Indonesia memiliki korelasi yang sangat rendah dengan alat ukur rasa syukur (Kazdin, 1995). Hal tersebut menunjukkan kedua alat ukur tersebut mengukur atribut yang berbeda. 
Analisis berikutnya yang dilakukan adalah estimasi reliabilitas. Untuk melihat apakah suatu alat ukur reliabel atau tidak diantaranya dapat menggunakan pendekatan konsistensi internal yaitu Alpha Cronbach (Cohen dan Swerdlik, 2009; Drost, 20I I; Neuman, 20I4).

Dalam penelitian ini, peneliti menggunakan pendekatan koefisien Alpha Cronbach terhadap alat ukur Team Trust dengan 4 dimensi yaitu propensity to trust, perceived trustworthiness, cooperative behaviors dan monitoring behaviors. Analisis ini dilakukan dengan menggunakan data sebanyak 572. Alat ukur Team Trust memiliki reliabilitas sebesar 0,9I2 yang menunjukkan bahwa alat ukur Team Trust memiliki reliabilitas yang tinggi (Guilford, I956).

Nilai reliabilitas tertinggi dalam alat ukur ini terdapat pada dimensi propensity to trust dengan nilai koefisien Alpha Cronbach sebesar 0,846. Sementara nilai reliabilitas terendah dalam alat ukur ini terdapat pada dimensi perceived trustworthiness dengan nilai koefisien Alpha Cronbach sebesar 0,66I namun masih masuk dalam kategori reliabilitas yang sedang. Sehingga hasil estimasi reliabilitas dengan koefisien Alpha Cronbach sebelum dilakukan modification indices dapat dikatakan bahwa alat ukur Team Trust memiliki reliabilitas yang sangat tinggi atau sangat reliabel (Guilford, I956).

Sementara itu, setelah dilakukan modification indices dan penghapusan item sebanyak 3 item dalam pengujian validitas konstruk yaitu confirmatory factor analysis peneliti kembali melakukan uji reliabilitas dengan metode yang sama yaitu menggunakan koefisien Alpha Cronbach. Hasil uji reliabilitas dengan jumlah item sebanyak I8 dan partisipan sebanyak 572 orang menunjukkan adanya perubahan nilai reliabilitas namun tidak signifikan. Perubahan nilai reliabilitas Alpha Cronbach untuk keseluruhan alat ukur yaitu dari 0,912 menjadi 0,930 .

Kemudian, nilai reliabilitas pada setiap dimensi yang berubah yaitu dimensi perceived trustworthiness dari 0,66I menjadi 0,684 dan dimensi cooperative behaviors dari 0,720 menjadi 0,868. Namun perubahan nilai reliabilitas tidak merubah kategori nilai dimana alat ukur team trust milik Costa dan Anderson (20II) yang diadaptasi ke Indonesia masih masuk dalam kategori sangat tinggi atau sangat reliabel. Tabel 5 menunjukkan perbandingan nilai koefisien Alpha Cronbach alat ukur team trust baik sebelum dan sesudah dilakukan modification indices.

Tabel 5. Perbandingan Reliabilitas Alpha Cronbach Alat Ukur Team Trust Sebelum dan Sesudah dilakukan Modification Indices

\begin{tabular}{|c|c|c|c|c|c|}
\hline \multirow[t]{2}{*}{ Dimensi } & \multirow[t]{2}{*}{$\overline{\mathrm{N}}$} & \multicolumn{2}{|c|}{ Sebelum Modification Indices } & \multicolumn{2}{|c|}{ Sesudah Modification Indices } \\
\hline & & $a$ & Kategori & $a$ & Kategori \\
\hline Propensity to trust & 572 & 0,846 & Tinggi & 0,846 & Tinggi \\
\hline Perceived trustworthiness & 572 & 0,661 & Sedang & 0,684 & Sedang \\
\hline Cooperative behaviors & 572 & 0,720 & Tinggi & 0,868 & Tinggi \\
\hline Monitoring behaviors & 572 & $0,8 \mathrm{IO}$ & Tinggi & $0,8 \mathrm{IO}$ & Tinggi \\
\hline Konstruk & $\mathrm{N}$ & $a$ & Kategori & $a$ & Kategori \\
\hline Team Trust & 572 & $0,9 \mathrm{I} 2$ & Sangat Tinggi & 0,930 & Sangat Tinggi \\
\hline
\end{tabular}

Berdasarkan tabel 4.8 menunjukkan bahwa total mean dalam penelitian ini adalah I3.65I9 dengan nilai signifikansi (p-value) berada pada rentang 0,000-0,766. Pada karakteristik lama kerja, mean tertinggi berada pada karyawan yang bekerja $\leq 3$ tahun $(\mathrm{m}=\mathrm{I5}$ 5.0186). Dalam bidang pekerjaan menunjukkan mean tertinggi berada pada karyawan yang bekerja di bidang pendidikan $(\mathrm{m}=24.4 \mathrm{I78})$ dan mean terendah pada bidang pekerjaan pemerintahan $(\mathrm{m}=\mathrm{II} .824 \mathrm{I})$. Kemudian, signifikansi sebesar 0,000 menunjukkan adanya perbedaan skor team trust pada bidang pekerjaan. 
Tabel 6. Uji Beda Demografis Partisipan

\begin{tabular}{|c|c|c|c|c|c|c|}
\hline Karakteristik & Bidang Pekerjaan & $\mathrm{N}$ & Persentase & Mean & $\bar{F}$ & Sig. \\
\hline \multirow[t]{5}{*}{ Bidang Pekerjaan } & Pemerintahan & 293 & $51,2 \%$ & II,824I & \multirow[t]{5}{*}{7,968} & \multirow[t]{6}{*}{,000 } \\
\hline & Swasta & 196 & $34,3 \%$ & 13,9237 & & \\
\hline & Kesehatan & 36 & $6,3 \%$ & 19,3642 & & \\
\hline & Pendidikan & 32 & $5,6 \%$ & $24,4 \mathrm{I} 78$ & & \\
\hline & Tidak Teridentifikasi & I5 & $2,6 \%$ & 9,1253 & & \\
\hline Total & & 572 & $100 \%$ & 13,6519 & & \\
\hline \multirow[t]{3}{*}{ Lama Kerja } & $\leq 3$ tahun (Masa Kerja Baru) & 337 & $58,9 \%$ & I5,0I86 & \multirow[t]{3}{*}{7.255} & \multirow[t]{3}{*}{.000} \\
\hline & $>3$ tahun (Masa Kerja Lama) & I9I & $33,4 \%$ & 12,9660 & & \\
\hline & Tidak Teridentifikasi & 44 & $7,7, \%$ & 6,1609 & & \\
\hline Total & & 572 & $100 \%$ & 13,6519 & & \\
\hline \multirow[t]{5}{*}{ Jabatan } & Staf & 342 & $59,8 \%$ & 13,7586 & \multirow[t]{5}{*}{, 459} & \multirow[t]{6}{*}{,766 } \\
\hline & Senior Staf & 180 & $3 \mathrm{I}, 4 \%$ & 13,2699 & & \\
\hline & Superior & 24 & $4,2 \%$ & $\mathrm{I} 5,5775$ & & \\
\hline & Manager & $\mathrm{I} 3$ & $2,3 \%$ & 16,0646 & & \\
\hline & Tidak Teridentifikasi & $\mathrm{I} 3$ & $2,3 \%$ & I0,I646 & & \\
\hline Tabel & & 572 & $\mathrm{I00} \%$ & 13,6519 & & \\
\hline \multirow[t]{7}{*}{ Jumlah Anggota dalam Unit } & $2-10$ & 176 & $30,8 \%$ & $\mathrm{I} 6,3655$ & \multirow[t]{7}{*}{3,682} & \multirow[t]{7}{*}{,00I } \\
\hline & II -20 & $\mathrm{I} 34$ & $23,4 \%$ & $\mathrm{I} 3,4840$ & & \\
\hline & $2 \mathrm{I}-30$ & 29 & $5,1 \%$ & I6,I528 & & \\
\hline & $3 I-40$ & $\mathrm{I} 3$ & $2,3 \%$ & I0,3I I 5 & & \\
\hline & $4 \mathrm{I}-50$ & 25 & $4,4 \%$ & $\mathrm{I} 0,5492$ & & \\
\hline & $>50$ & $\mathrm{I} 24$ & $21,6 \%$ & 9,5377 & & \\
\hline & Tidak Teridentifikasi & $7 \mathrm{I}$ & $\mathrm{I} 2,4 \%$ & I5,I099 & & \\
\hline Total & & 527 & $100 \%$ & 13,6519 & \multirow{7}{*}{$2,34 \mathrm{I}$} & \\
\hline Jumlah Anggota dalam & 2-10 & $\mathrm{I} 42$ & $24,8 \%$ & $\mathrm{I} 2,0058$ & & \multirow[t]{6}{*}{054} \\
\hline \multirow{4}{*}{ Divisi/Departemen } & II -50 & 176 & $30,8 \%$ & $\mathrm{I} 5,9607$ & & \\
\hline & 5I-I00 & $6 \mathrm{I}$ & $10,7 \%$ & $\mathrm{I} 3, \mathrm{I} 433$ & & \\
\hline & $>\mathrm{IOO}$ & 106 & $18,5 \%$ & II,7254 & & \\
\hline & Tidak Teridentifikasi & 87 & $\mathrm{I} 5,2 \%$ & $\mathrm{I} 4,37 \mathrm{I} 5$ & & \\
\hline Total & & 572 & $100 \%$ & 13,6519 & & \\
\hline
\end{tabular}

Sementara itu, signifikansi sebesar 0,OOI menunjukkan bahwa terdapat perbedaan skor team trust pada karakteristik lama kerja. Hal ini dapat diartikan bahwa karyawan dengan kategori masa kerja baru cenderung memiliki skor team trust yang lebih tinggi dibandingkan dengan karyawan dengan masa kerja lama. Karakteristik jabatan menunjukkan mean tertinggi berada pada karyawan yang menjabat sebagai manager $(\mathrm{m}=\mathrm{I} 6.0646)$ dan mean terendah berada pada karyawan yang menjabat sebagai senior staf $(\mathrm{m}=\mathrm{I} 2.2699)$.

Signifikasi jabatan adalah sebesar 0,766 yang menunjukkan bahwa tidak ada perbedaan skor team trust pada karyawan yang menjabat sebagai staf, senior staf, supervisor maupun manager. Hal ini menunjukkan bahwa team trust tidak dipengaruhi oleh jabatan yang dipegang oleh karyawan tersebut. Pada karakteristik jumlah anggota dalam unit mean tertinggi berada pada karyawan yang memiliki jumlah anggota dalam unit sebanyak 2-I0 orang $(\mathrm{m}=\mathrm{I} 6.1528)$ dan mean terendah berada pada karyawan yang memiliki anggota dalam unit sebanyak $>50$ orang $(\mathrm{m}=9.5377)$.

Dengan signifikansi sebesar 0,OOI menunjukkan adanya perbedaan skor team trust yang signifikan pada jumlah anggota dalam unit. Hal ini dapat diartikan dengan semakin sedikit jumlah anggota dalam unit maka semakin tinggi pula team trust karyawan tersebut.

Pada karakteristik jumlah anggota dalam divisi/departemen menunjukkan bahwa mean tertinggi pada karyawan yang memiliki jumlah anggota dalam divisi/departemen sebanyak II-50 orang $(\mathrm{m}=15.9607)$ dan mean terendah pada karyawan yang memiliki jumlah anggota dalam divisi/departemen sebanyak >I00 $(\mathrm{m}=\mathrm{II}$.7254). Dengan signifikasi sebesar 0,054 menunjukkan tidak adanya perbedaan skor team trust yang signifikan pada karakteristik jumlah anggota dalam divisi/departemen. Hal ini menunjukkan bahwa jumlah 
anggota dalam divisi/departemen seorang karyawan tidak akan memengaruhi bagaimana kepercayaan karyawan tersebut pada timnya.

\section{Penutup}

Penelitian ini menunjukkan bahwa alat ukur Team Trust milik Costa dan Anderson (20II) yang diadaptasi ke Indonesia valid dan reliabel. Hal tersebut ditunjukkan dengan hasil uji validitas konstruk yaitu confirmatory factor analysis dengan nilai indeks kecocokan sebesar 0,07 (RMSEA), 0,04 (SRMR), 0,93 (CFI) dan 0,92 (TLI), validitas konvergen antara alat ukur team trust dengan employee engagement dan komitmen organisasi dengan masing -masing nilai pearson correlation sebesar 0,53 dan 0,6I.

Kemudian hasil uji validitas diskriminan antara alat ukur team trust dengan rasa syukur menunjukkan nilai pearson correlation sebesar 0,06. Sementara itu, uji reliabilitas dengan koefisien Alpha Cronbach menunjukkan nilai 0,930. Hasil pengujian tersebut menunjukkan bahwa alat ukur team trust milik Costa dan Anderson (20II) dengan 4 dimensi dan I8 item yang diadaptasi ke Indonesia valid dan reliabel.

Hasil uji beda menunjukkan terdapat perbedaan yang signifikan pada karakteristik bidang pekerjaan, lama kerja dan jumlah anggota dalam unit. Sementara itu, jabatan dan jumlah anggota dalam divisi/departemen menunjukkan tidak adanya perbedaan yang signifikan sehingga dapat diartikan bahwa tidak ada perbedaan skor team trust pada karakteristik jabatan dan jumlah anggota dalam divisi/departemen.

\section{Daftar Pustaka}

Anastasia, A. Urbina, S. (1997) Tes psikologi edisi bahasa Indonesia. Jakarta: PT. Prenhalindo.

Azwar, S. (2015). Dasar-dasar psikometrika: edisi II. Yogyakarta: Pustaka Pelajar.

Bakti, D. (2013). Studi Indigeneous Trust to Leader pada Karyawan Jawa. Skripsi. Universitas Negeri Semarang (online).

Bakioglu, F., Turkum, A. (2017). Pychometric properties of adaptation of the social efficacy and outcome expectations scale to Turkish. European Journal of Educational Research. 6, (2), 2I3-223.

Byrne, B. (1998). Structural Equation Modeling with lisrel, prelis and simplis: Basic concept, application and programming. Mahwah. New Jersey: Lawrence Erlbaum Associates, Inc.

Cangur, E, G., Ercan, I. (2015). Comparison of model fit indices used in structural equation modeling under multivariate normality. Journal of Modern Applied Statistical Methods. I4, (I), I52-I67.

Costa, A., Anderson, N. (201I). Measuring trust in teams: development and validation of a multifaceted measure of formative and reflective indicators of team trust. European Journal of Work and Organizational Psychology. 20, (I), I I9-I54.

Cozby, P., Bates, S. (2015). Methods in Behavioral Research. New York: McGraw Hill Education.

Dirks, K., Ferrin, D. (2002). Trust in leadership: meta-analytic findings and implications for research and practice. Journal of Applied Psychology. 87, (4), 6I I-628.

Ghozali, I., Fuad. (2008). Structural Equation Modeling. Semarang: Universitas Diponegoro.

Grasiaswaty, N., Juwita, F., Setyasih, N. (20I4). Adaptasi alat ukur organizational citizenship behavior (OCB) dengan peer review di Indonesia. Seminar Asean $2^{\text {nd }}$ Psychology and Humanity. 317-325.

Guilford, J. (1956). Fundamental statistic in psychology and education $3^{\text {rd }}$ ediion. New York: McGraw-Hill Book Company, Inc. 
Hair, J, F., Black, W, C., Babin, B, J., Anderson, R. (2010). Multivatiate Data Analysis (7th ed.). New Jersey: Pearson Education, Inc.

Ingarianti, T. (2015). Pengembangan alat ukur komitmen organisasi. Jurnal RAP UNP. 6, (I), 80-9I.

Kazdin, A. (1995). Preparing and evaluating research reports. Psychological Assessment. 7, (I), 228-237.

Kim, U. (2000). Indigeneous, cultural, and cross cultural psychology: a theoretical, conceptual and epistemological analysis. Asian Journal of Social Psychology. 3, 265-287.

Kim, U., Berry, J. (1993). Indigeneous psychologies: experiences and research in cultural context. Newbury Park: Sage Publications.

Kimberlin, C., Winterstein, A. (2008). Validity and reliability of measurement instruments used in research. American Journal of Health-System Pharmacy. 65, (23), 227-2284.

Kirikkanat, B., Soyer, M. (2016). Adaptation of the academic coping strategies scale in Turkey: a study with undergraduates. International Journal of Teaching and Education. 4, (I), 26-44.

Kramer, R. (1999). Trust and distrust in organizations: emerging perspectives, enduring questions. Annual Review of Psychologyy. 50, 569-598.

Kothari, C. (2004). Research Methodology methods \& techniques second revised edition. New Age International Publisher: New Delhi.

Listiandini, R. (20I5). Mengukur rasa syukur: pengembangan model awal skala bersyukur versi Indonesia. Jurnal Psikologi Ulayat. 2, (2), 473-496.

MacCallum, R., Browne, M., Sugawara, H. (1996). Power analysis and determination of sample size covariance structure models. Multivatriate Behavioral Research. (29), 1032.

Mayer, R., Davis, J. (I999). The effect of the performance appraisal system on trust for management: a field quasi-experiment. Journal of Applies Psychology. 84, I23-I36.

Norman, S., Avolio, B., Luthans, F. (2010). The impact of positivity and transparency on trust in leaders and their perceived effectiveness. Elsevier: The Leadership Quarterly. 2I, 350-364.

Owonikoko, E. (2016). Building and maintaining trust in virtual teams as a competitive strategy. Walden Dissertations and Doctoral Studied Collection. I-2IO.

Pramudyo, A. (2013). Implementasi manajemen kepemimpinan dalam pencapaian tujuan organisasi. Jurnal JBMA. I, (2), 49-6I.

Puusa, A., Tolvanen, U. (2006). Organizational identity and trust. Electronic Journal of Business Ethics and Organization Studies. I I, (2), 29-33.

Rachmayani, D., Ramdhani, N. (20I4). Adaptasi bahasa dan budaya skala psychological well-being. Proceeding Seminar Nasional Psikometri. 253-268.

Raharso, S. (20I I). Kepercayaan dalam tim. Jurnal Manajerial. I0, (19), hlm. 42-53.

Reina, D., Reina, M., Hudnut, D. (2017). Why trust is critical to team trust. Research Report, Center for Creative Leadership. I-I4.

Riva, S., Gorini, A., Cutica, I., Mazzocco, K., Pravettoni, G. (20I5). Translation, cross-cultural adaptation, and reliability of the Italian version of the passive risk taking (PRT0 scale. Judgement and Decision Making. I0, (6), 597-604. 
Shaughnessy, J., Zechmeister, E., Zechmeister, J. (2012). Research Methods in Psychology $9^{\text {th }}$ ed. New York: McGraw Hill.

Soler, F., Lugo, M., Espada, J., Morales, A., Sierra, J., Bertrand, L., Medina, P. (2016). Adaptation and validation of the brief sexuality scale in Colombian and Spanish populations. International Journal of Psychology and Psychological Therapy. 16, (3), 342-356.

Spector, M., Jones, G. (2004). Trust in the workplace: factors affecting trust formation between team members. The Journal of Social Pscyhology. I44, (3), 3 II.

Susiawan, S., Muhid, A. (2015). Kepemimpinan transformasional, kepuasan kerja dan komitmen organisasi. Persona, Jurnal Psikologi Indonesia. 4, (3), 304-313.

Taherdoost, H. (2016). Sampling methods in research methodology; how to choose a sampling technique for research. International Journal of Academic Research in Management (IJARM). 5, (2), I8-27.

Titien. (2016). Penyusunan dan pengembangan alat ukur employee engagement. PSIKOHUMANIORA: Jurnal Penelitian Psikologi. I, (I), I I3-I30.

Toprak, M., Karakus, M. (2018). Teacher's moral intelligence: a scale adaptation into Turkish and preliminary evidence. European Journal of Education Research. 7, (4), 901-9II.

Tyler, R. (2003). Trust within organizations. Personnel Review. 32, (5), 556-568.

Utamaningsih, A. (2009). Dimensi kepercayaan sebagai mediasi pengaruh gaya kepemimpinan, komitmen dosen kontrak PTS di kota Malang. Jurnal Administrasi dan Bisnis. 3, (I), 44-56.

Wicaksana, Y., Efar, M., Mewengkang, M., Miranti, I., halim, M., Suwartono, C. (2012). Adaptasi skala organizational citizenship behavior (OCB). Manasa. I, (2), 24I-254.

Widodo, P. (2006). Reliabilitas dan validitas konstruk skala konsep diri untuk mahasiswa Indonesia. Jurnal Psikologi Universitas Diponergoro. 3, (I), I-9.

Yozgat, U., Mesekiran, G. (2016). The impact of perceived ethical leadership and trust in leader on job satisfaction. Journal of Economics, Business and Management. 4, (2), I23-I3I. 